\title{
Hydrogen and oxygen isotopic compositions of subsurface water at Bajawa area, central Flores, Indonesia
}

\author{
Masaaki TAKAHASHI ${ }^{1}$, Minoru URAI², Kasumi YASUKAWA ${ }^{3}$, \\ Hirofumi MuraOKa ${ }^{3}$, Koji MATSUdA ${ }^{4}$, Hideo AKASAKO ${ }^{4}$, \\ Takehiro KoseKi ${ }^{5}$, Koichi Hisatani ${ }^{6}$, Dedi Kusnadi', \\ Bangbang SUlAEMAN ${ }^{7}$, Terry SRIWANA ${ }^{8}$ and Asnawir NASUTION ${ }^{8}$
}

\begin{abstract}
Masaaki Takahashi, Minoru Urai, Kasumi Yasukawa, Hirofumi Muraoka, Koji Matsuda, Hideo Akasako, Takehiro Koseki, Koichi Hisatani, Dedi Kusnadi, Bangbang Sulaeman, Terry SRIwANA and Asnawir NASUTION (2002) Hydrogen and oxygen isotopic compositions of subsurface water at Bajawa area, central Flores, Indonesia. Bull. Geol. Surv, Japan, vol. 53 (2/3), p. 201-209, 5 figs., 3 tables.
\end{abstract}

\begin{abstract}
Samples of spring and stream water, and rainfall were obtained within $50 \mathrm{~km}$ of Bajawa City, central part of Flores Island, eastern Indonesia. Hydrogen and oxygen isotopic compositions of the samples were analyzed.

(1) On the relation diagram between hydrogen and oxygen isotopic compositions, water samples were plotted near the meteoric water line. The sample d-values taken in 1998 and 1999 were about 10 and 20, respectively. The change of d-value may reflect the isotopic difference of rainfall in winter and summer.

(2) Altitude (topographical) effects for hydrogen and oxygen isotopic compositions of subsurface water in this area were $-0.98 \% / 100 \mathrm{~m}$ for hydrogen isotopic composition and $-0.13 \% 0 / 100 \mathrm{~m}$ for oxygen isotopic composition, which were within the range of those found for other islands.
\end{abstract}

\section{Introduction}

Characteristics of hydrogen and oxygen isotopic variations of subsurface water and rainfall due to topographical elevation have been used to infer recharge areas for groundwater or hot spring water, indicate mixing, or delineate different groundwater or hydrothermal system. However, there were no hydrogen and oxygen isotopic data for subsurface

${ }^{1}$ Research Center for Deep Geological Environments, GSJ

${ }^{2}$ Institute of Geoscience, GSJ

${ }^{3}$ Institute of Geo-Resources and Environment, GSJ

${ }^{4}$ West Japan Engineering Consultants, Inc., Watanabedori 2-1-82, Chuo, Fukuoka, 810-0004 Japan

${ }^{5}$ Mitsubishi Materials Natural Resources Development Corp., Nihonbashi Hamacho 3-21-1, Chuo, Tokyo, $103-$ 0007 Japan

${ }^{6}$ New Energy and Industrial Technology Development Organization, Sunshine 60, 30F, Higashi-Ikebukuro 3-11, Toshima, Tokyo, 170-6030 Japan (present address: Metal Mining Agency of Japan, Toranomon 1-24-14, Minato, Tokyo, 105-0001 Japan)

${ }^{7}$ Directorate of Mineral Resources Inventory, Jl. SoekarnoHatta 444, Bandung, 40254 Indonesia

${ }^{8}$ Directorate of Volcanology and Geological Hazard Mitigation J1. Diponegoro No.57, Bandung, 40122 Indonesia water of the eastern part of Indonesia except Bali Island (e.g. Shimada et al., 1992a) and knowledge of subsurface water flow patterns was also so limited.

Precipitation patterns on islands with appreciable topography are very complex, and precipitation isotope data from the International Atomic Energy Agency (IAEA) island stations commonly exhibit patterns different from those found on other continental stations (Yurtsever and Gat, 1981; Dansgaard, 1964). Scholl et al. (1996) showed that significant areal differences in precipitation isotopes on the island of Hawaii correlated strongly with general climatological patterns. High rainfall areas have frequent rains owing to the orographic lifting of moist air carried by trade winds or the thermally driven sea breeze cycle. Tang et al. (1998) described that on Miyake Island, even at places of the same altitude, the precipitation was different because of the aspect of the landscape and also found that oxygen isotopic compositions for the windward and leeward sides were different from that for precipitation.

The purpose of this study is (1) to show isotopic distributions of subsurface water and rainfall in the

Keywords: hydrogen isotope, oxygen isotope, subsurface water, meteoric water line, d-value, altitude effect, Bajawa, Flores, Indonesia 

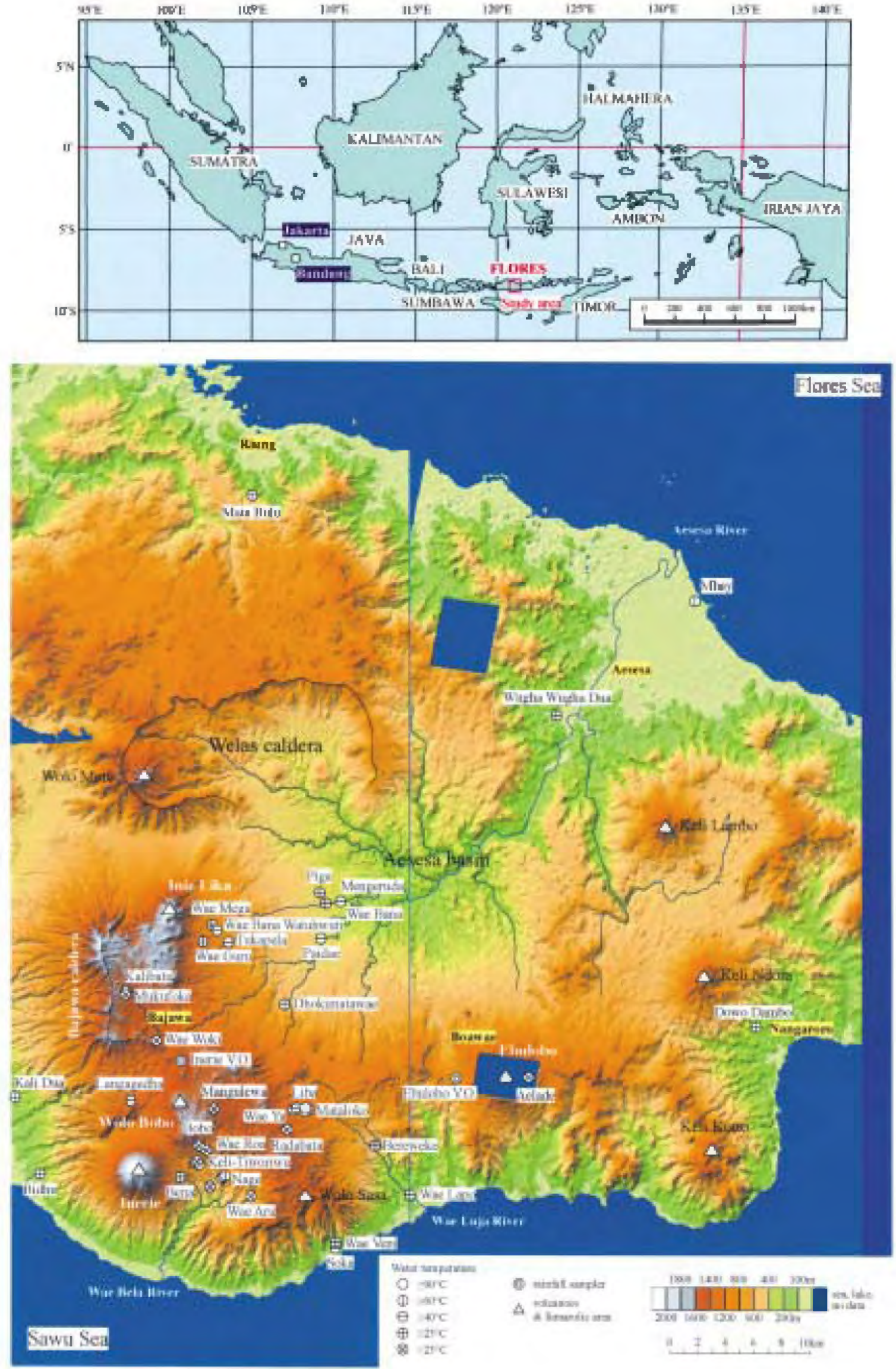

Fig. 1 Locality map of sampling points of spring water, stream water and rainfall sampled in 1997-1999. 
Bajawa area, central part of Flores Island, about $500 \mathrm{~km}$ east of Bali Island, and (2) describe the topographical (altitude) effects for isotopic compositions of subsurface water.

\section{Study area}

The islands of Nusa Tenggara span a distance of 1,300 kilometers and lie 8 to 10 degrees south of the equator. They connect the Greater Sunda Islands in the west to the scattered islands of Maluku, Banda Islands and large island of Irian Jaya to the east forming a central link in the 5,600 kilometer Indonesian archipelago. They form two distinct arcs. The long northern arc, Lombok, Sumbawa, Komodo, Flores, Lembata, Alor and other islands is volcanic in origin. The islands of the shorter southern arc, Sumba, Savu, Rote, Timor and other islands are formed of raised coral reef limestone and pelagic sedimentary rocks (e.g. Hamilton, 1979). Most of those volcanic islands have the potential to provide geothermal energy (e.g. PERTAMINA, 1994). Flores Island is in the eastern part of the Nusa Tenggara Islands and a long, narrow island $350 \mathrm{~km}$ long (east to west) and 20-70 $\mathrm{km}$ wide (north to south). Bajawa City is in the central part of the island and the provincial capital of the Ngada prefecture. In the Bajawa area, there are two volcanic alignments (Fig. 1). The southern-coast-side volcanic alignment is a volcanic front and contains three active volcanoes, Inerie $(2160 \mathrm{~m})$, Inie Lika $(1800 \mathrm{~m})$ and Ebulobo $(2150 \mathrm{~m})$, and more than 30 monogenetic volcanoes. The average height of the southerncoast-side volcanic row (plateau) is $1000-1500 \mathrm{~m}$ (see Takahashi et al. (2002, Fig. 7)). On the other hand, the northernside volcanic alignment is a back-arc volcanic row and contains the cocoon-shaped Welas caldera $15 \mathrm{~km}$ (east to west) by $8 \mathrm{~km}$ (north to south) and post-caldera cone called Mt. Wolo Mere $(1550 \mathrm{~m})$. The average height of the northernside volcanic row (plateau) is $500-1000 \mathrm{~m}$ (see Takahashi et al. (2002, Fig. 7)). This setting is similar to double volcanic belts in the northeast Japan arc (Muraoka et al., 1999). Both volcanic rows rise straight up from the Flores and Sawu Seas. There is an elliptic large basin $20 \mathrm{~km}$ (east to west) by $15 \mathrm{~km}$ (north to south) sandwiched by two volcanic alignments (Fig. 1). Muraoka et al. (1999) named the basin, the Aesesa Basin. The average elevation of the basin is $300 \mathrm{~m}$ and becomes lower gradually toward the northeastern coast. There are three large river systems in the Bajawa area (Fig. 1). The Aesesa River, which is the longest river in this area flows to the northeast and discharges into the Flores Sea. The Wae Bela River starts in a small basin near Nage and flows to the southwest. The Wae Luja River starts from the northeastern side of the southernside volcanic row and runs to the southeast. The latter two rivers discharge into the Sawu Sea.

In Indonesia, every volcano observatory (V. O.)

Table 1 Monthly precipitation data (precipitation amount and number of rainy days) and Q-values at the Inerie and Ebulobo volcano observatories from 1996 to 2000.

\begin{tabular}{|c|c|c|c|c|c|c|c|c|}
\hline & \multicolumn{2}{|c|}{ hertig } & \multirow{2}{*}{ E. $\Delta$} & \multirow{2}{*}{ I nitus } & \multicolumn{2}{|c|}{ thick bo 10} & \multirow{2}{*}{$\bar{N}=\mathrm{D}$} & \multirow{2}{*}{ Dovere } \\
\hline & (ans? & (bass) & & & (men) & (a)ye) & & \\
\hline $\ln |x|$ & $2 \pi$ & 16 & 是 & \multirow{12}{*}{ I D } & 533. & 15 & IE & \multirow{12}{*}{17} \\
\hline Fush & All & IA & A & & $28 \%$ & 13. & is. & \\
\hline Marif & IHA & 17 & E & & 37. & 3. & $\overline{5}$ & \\
\hline Apr: $=5$ & $\pi$ & 3 & & & 53. & 2 & D & \\
\hline $36 y .96$ & 96. & 4 & $D$ & & I9. & d & II. & \\
\hline Inn 94 & 4. & ㅁ. & D & & ह. & a. & $\mathbf{\square}$ & \\
\hline bulite & a. & 口 & $D$ & & te. & a. & 므. & \\
\hline Aar. 86 & II & 1 & $\mathrm{D}$ & & s. & 1 & ப & \\
\hline $3 x^{2} 4$ & $a$ & u & $D$ & & 2 & 0. & [] & \\
\hline 나닐 & 137 & 4 & & & e. & 2 & & \\
\hline Bine & 1005 & II & EE & & 160.5 & $\bar{c}$ & 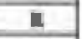 & \\
\hline$D=6$. & 9117 & 17 & H & & 3s. & 4. & L & \\
\hline $\ln (\mathrm{ng}$ & 54 & 18 & $\mathrm{H}$ & \multirow{12}{*}{$1=$} & IH & II & 只 & \multirow{12}{*}{125} \\
\hline Fat & $6 n$ & 21 & h. & & IL & 17 & 므 & \\
\hline Nur जा & $2 n$ & 6. & H & & $\pi$. & 3 & & \\
\hline Apring & $\operatorname{los} 3$ & $\underline{6}$ & i. & & IJI. & 1 & I & \\
\hline Bey जा & 64 & 1 & $D$ & & $\alpha 2$ & 2 & & \\
\hline has जा & 33. & 1 & D & & $\pi$ & 1 & & \\
\hline$M v \pi$ & a. & u. & D & & e. & a. & D & \\
\hline Ausg & a. & 0 & D & & 17 & 1 & 믄 & \\
\hline 54797 & a. & i & D & & e. & a & 口 & \\
\hline nan & a. & $\bar{u}$ & D & & 4 & D & $\pi$ & \\
\hline Near, m? & 33.5 & 4 & D & & 33 & 3 & $D$ & \\
\hline$D a=97$ & 3512 & 18. & i & & 241 & II & I & \\
\hline Inn 18 & $15 \times 8$ & II. & II & \multirow{12}{*}{090} & III: & 14 & 旦 & \multirow{12}{*}{4.5} \\
\hline Febve & 3248 & 16. & it & & m & 14 & ii & \\
\hline Mor 48 & 35 , & 14. & I & & 레 & If & H & \\
\hline hys bef & 3052 & 14. & it & & 311 & 13 & R & \\
\hline Mey Se] & 34 & 6. & & & ग & 1 & $D$ & \\
\hline lin in & 22 & 8 & D & & 1 & L & D & \\
\hline Mase & 321 & 1 & & & II & 3 & & \\
\hline Mas 38 & a. & a & ப & & 119 & 2. & $D$ & \\
\hline 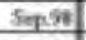 & 336 & 4 & $\square$ & & 4 & 4 & D & \\
\hline Oast & 311 & 12 & & & $1 \pi$ & 3. & H & \\
\hline Niaral & 44. & 20 & II & & 253 & 13 & H & \\
\hline $\mathrm{D}=\mathrm{s} 8$ & 4911 & 18 & H & & 721. & 14 & B & \\
\hline Jenive & ILI) & $2 \pi$ & H & \multirow{12}{*}{ us } & Sas 5 & 23. & Ii. & \\
\hline Foh & 3646 & II & A & & 48.5 & 18 & II & \\
\hline Mar 7 & 2024 & II & II & & 522 & 21 & iE & \\
\hline Apr. 90 & 계.1 & 14 & A & & 202 & 13 & II & \\
\hline Ney.90 & 12 & 1 & $D$ & & in. & 2 & D & \\
\hline han & 918 & 9 & & & 1415 & 2 & i & \\
\hline nos & 9 & 口 & DI & & $T$ & 3 & D & \\
\hline $\operatorname{sen} 00$ & a. & 口 & $\Pi$ & & 35 & L & D & \\
\hline $\operatorname{sen} 6$ & a. & D & $D$ & & 4 & $t$ & D & \\
\hline $0 \pm 0$ & 113 & 3 & $\mathrm{D}$ & & 68. & 2 & & \\
\hline New. 70 & $\sin 4$ & II & P & & & & & \\
\hline$D=30$ & 2442 & 17 & $\mathrm{~A}$ & & & & & \\
\hline 1- & गJ1 & $\pi$ & H & \multirow{12}{*}{ 057 } & & & & \\
\hline Inas & 페? & 17 & in & & 482 & 21 & I & \\
\hline heros & SI & 21 & B & & & & & \\
\hline Are to & पू & 19 & B & & & & & \\
\hline May too & 2097 & 16 & H & & 297. & is: & E & \\
\hline $\ln 10$ & 104 & 1 & D & & 165. & 14 & $n$ & \\
\hline $3-100$ & $a$ & n & D & & 4. & L & ㅁ & \\
\hline Mar 00 & d. & a & D & & 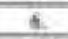 & 2 & I] & \\
\hline Strot & $7 n$ & 1 & D & & 13 & 1 & D & \\
\hline Detis & mas & 4 & & & 105.5 & 9 & I & \\
\hline $\mathrm{N}=\mathrm{w}$ & 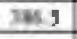 & 15 & B. & & 258 & 16. & II & \\
\hline$I=00$ & 9453 & 7 & n & & 271.5 & 12 & II & \\
\hline
\end{tabular}

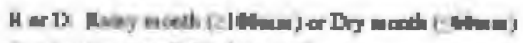

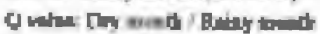


monitors the amount of rainfall. Monthly precipitation data at the Inerie and Ebulobo volcano observatories (Fig. 1) are shown in Table 1. In the table, Q-value, which is the ratio between the number of dry months when the monthly precipitation amount is less than $60 \mathrm{~mm}$ and number of rainy months when the monthly precipitation amount is more than $100 \mathrm{~mm}$, was also shown (e.g. Center for Southeast Asian Studies, Kyoto University, 1997, p. 468). The Q-values of this area, Sapporo, Tokyo, Osaka and Naha were 0.5-1.4, 0.2, 0.29, 0.29 and 0, respectively, calculated from Table 1 and monthly mean precipitation amounts from 1961 to 1990 shown in the Chronological Scientific Tables 2000. Relatively large Q-values of this area show the existence of the dry season and were concordant with the climatic classification of this area, Tropical Savannah (As). Precipitation amounts were 1200-2500 $\mathrm{mm} / \mathrm{yr}$ at the Ebulobo V. O. and $1700-2500 \mathrm{~mm} / \mathrm{yr}$ at the Inerie $\mathrm{V}$. O.

\section{Sampling and analytical methods}

Location of sampling points is shown in Fig. 1. Water samples were obtained from springs, streams and rainfall within $50 \mathrm{~km}$ of the Bajawa City from 1997 to 1999. Rainfall samplers of $9 \mathrm{~cm} \phi$-funnel and 20 1-backet (Kazahaya and Yasuhara, 1994; Scholl et al., 1995) were installed at the Inerie and Ebulobo volcano observatories to collect rainfall from July 1998 to September 1999. Methods for hydrogen and oxygen isotopic analyses were shown in Takahashi et al. (2002).

\section{Results and discussions}

4.1 The d-values of water samples of springs, streams and rainfall

The relation between hydrogen and oxygen isotopic compositions of water samples from springs, streams and rainfall is shown in Fig. 2. Craig (1961) described the interdependence of hydrogen and oxygen isotopic compositions in meteoric water and defined the following relationship:

$$
\delta \mathrm{D}=8 \mathrm{x} \delta \delta^{18} \mathrm{O}+10
$$

The relationship was generally described as the $\mathrm{Me}-$ teoric Water Line (MWL). Dansgaard (1964) defined the intersect for the $\mathrm{Y}$-axis $\left(\delta \mathrm{D}-8 \mathrm{x} \delta^{18} \mathrm{O}\right)$ as $\mathrm{d}$ value. As shown in Fig. 2 and Table 2, almost all water samples were plotted near the MWL. The

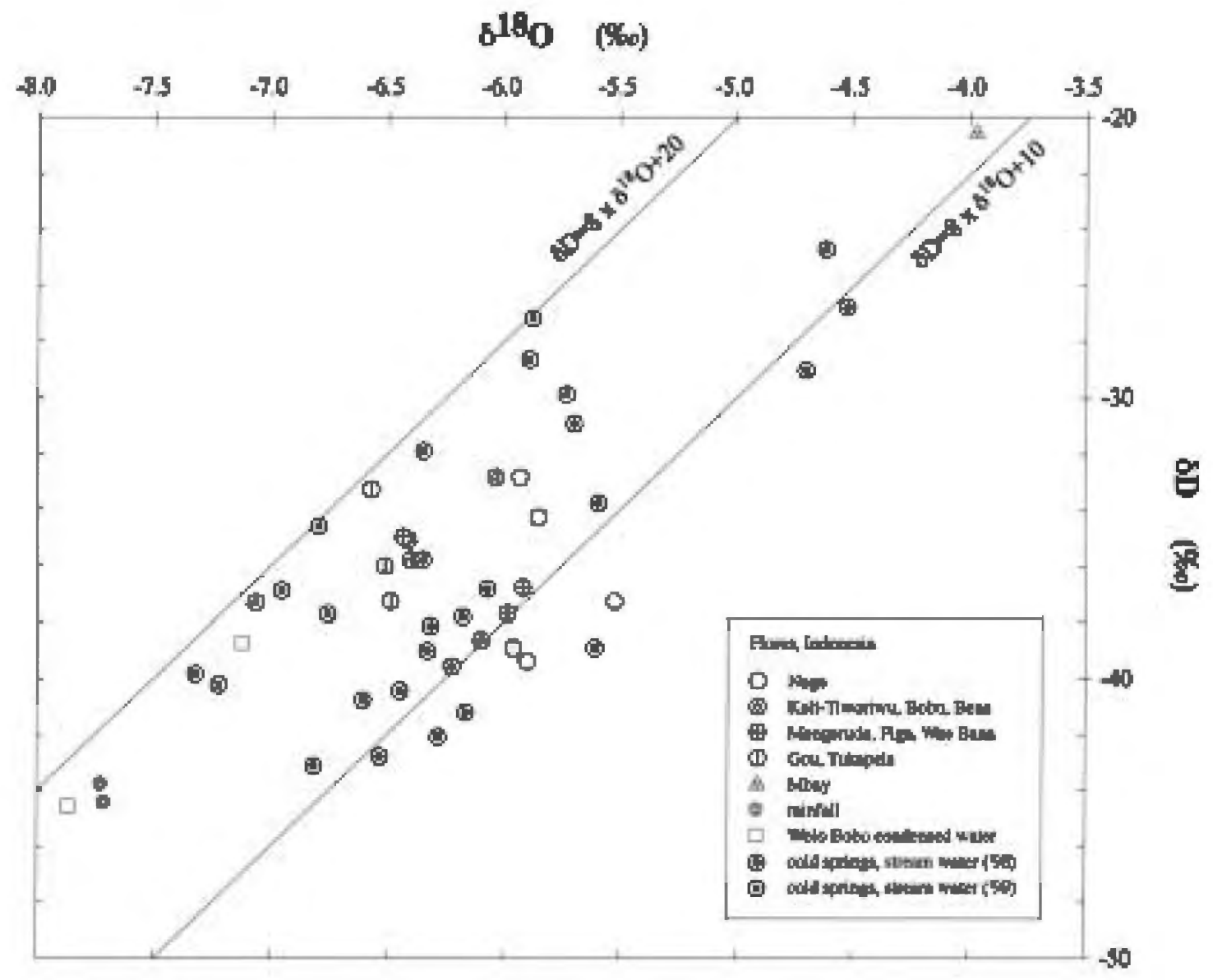

Fig. 2 The relation between hydrogen and oxygen isotopic ratio of spring water, stream water and rainfall on Flores Island, eastern Indonesia. 
Table 2 The result of hydrogen and oxygen isotopic analyses of spring water, stream water, condensed water and rainfall sampled in fiscal years 1997, 1998 and 1999. In the table, altitudes of the sampling points are also shown.

\begin{tabular}{|c|c|c|c|c|c|}
\hline \multirow{2}{*}{ angite nets } & \multirow{2}{*}{$\begin{array}{c}\text { Dewneste } \\
\text { nowele }\end{array}$} & \multirow{2}{*}{$\frac{\omega D}{N=1}$} & \multirow{2}{*}{$\frac{a^{2} 0}{4}$} & \multirow{2}{*}{ Arabe } & \multirow{2}{*}{$\frac{\text { losin }}{\text { nin }}$} \\
\hline & & & & & \\
\hline Nage-1 & bo & -3003 & $-5 \times r_{4}$ & 172 & 937 \\
\hline $\mathrm{Nane}-2$ & 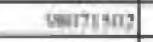 & 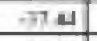 & 553 & 6.2 & 12 \\
\hline hinge-1 & 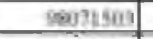 & 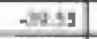 & -1917 & 77 & 912 \\
\hline Hear Was Tmul & 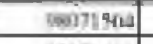 & 901 & $-5 \sin$ & $9 n 3$ & 19 \\
\hline Sorent of Meiclest & 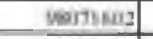 & -4736 & 620 & 305 & 100 \\
\hline HeVoigreft & 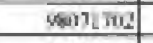 & 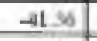 & AIT] & sing & 1100 \\
\hline Ihe & जकाา ता5 & 474 & काखा & 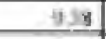 & Itol \\
\hline 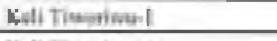 & yomitu| & -3479 & $\rightarrow \quad n$ & 1613 & I4i \\
\hline Kefi Tras mere? & 9eeriforg & $-39 \mathrm{mon}$ & $-1 \mathrm{AH}$ & $15: 9$ & 110 \\
\hline Salren of birli Tmime & 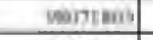 & 3 का & Ant & $11+0$ & U9L \\
\hline Mngevis & Soir?teui & -3101 & -9.007 & 1009 & 312 \\
\hline We Bira & (sempon] & 3695 & -542 & $111 \pm 3$ & 36 \\
\hline $\cos ($ Wis Mrall & moinzonit & $-w_{17}$ & -1153 & 160 & $\mathbf{E S O}$ \\
\hline 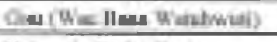 & sev7sina & -340 & -4509 & $10>3$ & nege \\
\hline 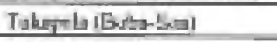 & 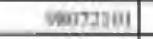 & -742 & a 2 에 & $14 \pm 6$ & 739 \\
\hline Naise $[W=W$ Weta & seusgut & -313 & $-6 \times 78$ & 1234 & 398 \\
\hline 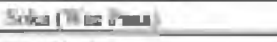 & 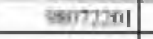 & अ & -5.719 & 1465 & 80 \\
\hline$W=V$ ini & 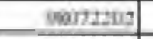 & 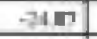 & and & 1217 & 110 \\
\hline$W=\mathrm{Hn}$ & sempol & 4100 & $-4 x>3$ & 113 & I029 \\
\hline Adv $[\mathrm{a}=\mathrm{n}=\mathrm{s}$ & mantung & 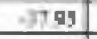 & 0.140 & 1137 & 1090 \\
\hline $4=$ Dans & $\operatorname{sen} 2+01$ & $=2013$ & -6 เง & 114 & W6: \\
\hline Dboummans & sentiang & $3 \times 2$ & -411 . & III in & 990 \\
\hline Bolafiche & simpai & -7 का ? & tinla & 119 & 1219 \\
\hline$h_{i}=W \mathrm{da}$ & searz2\%g & 3973 & -624 & I0 16 & 1192 \\
\hline $4=1$ ase & 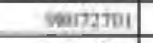 & 4096 & 430 & log & $1 \mathrm{~N}$ \\
\hline Marwole & sar? & -30 II & -9 मा & I0 0 & 45 \\
\hline 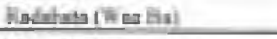 & जलायख्या & 3597 & -6_⿲丶丶㇒木 & 1401 & Iite \\
\hline Negengin! & woitsaus & $\rightarrow=1$ & -6.453 & 11 in & 45 \\
\hline$\psi=4$ & $90072 \mathrm{~min}$ & .51 10 & -4 & 10 & a:b \\
\hline l.mpupotha & 90019) & -10III & $-7 \times 30$ & 11100 & $\ln 30$ \\
\hline Kative & 300013미 & $-57 \mathrm{~m}$ & -6 क्जा & 1368 & 198: \\
\hline Mingufua & 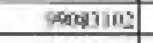 & $34+0$ & $-7 \operatorname{ing}$ & 1413 & 1279 \\
\hline Met, alearic Whe Ruel & ज्या। & 136 & 7233 & 1730 & 1:길 \\
\hline Aclele (Beane) & SRAFLEDI. & -17 & - & $16>3$ & 450 \\
\hline 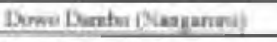 & 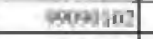 & 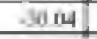 & -474 & $13 y 1$ & J \\
\hline Suta Fulb Prenf! & 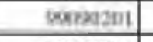 & $-17 \mathrm{~nm}$ & -6362 & $18 \mathrm{s5}$ & 458 \\
\hline Kelithe (himati) & supvil & 213 & $4 \mathrm{~min}$ & $19 \mathrm{m1}$ & 127 \\
\hline 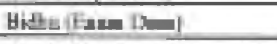 & Forifiged & 1374 & A.807 & 197 & 480 \\
\hline 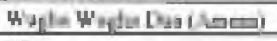 & Musin| & - 필 & -9095 & $11, \Omega$ & 9I \\
\hline Sari & 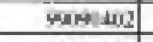 & -3053 & - Jens & $11 \geq 3$ & 30 \\
\hline $\mathrm{N}=1$ & serrient & -21111 & 4947 & 1453 & 139 \\
\hline Nase-7 & movitos & -411 & and & 1759 & 923 \\
\hline Hese & moving & 354 & -6 지 & $15=0$ & 160 \\
\hline Mophenta & wopdes & -24.16 & -4.47 & It $\Delta \Omega$ & 312 \\
\hline Whale Hahr-2 & yongstai & -139 & -2713 & $1+23$ & 1400 \\
\hline 4. & 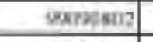 & -4380 & 7735 & 17.99 & ILip \\
\hline Len to misfon & a) $7-9+9$ & $-4+101$ & $-7 \times 73$ & 1173 & 1200 \\
\hline 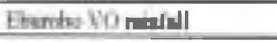 & (4) $7-89$ ) & $\begin{aligned} 39 \\
+35\end{aligned}$ & A129 & 1018 & 12ta \\
\hline
\end{tabular}

sample d-values taken in 1998 and 1999 were about 10 and 20, respectively. The d-values of rainfall samples taken from July 1998 to September 1999 were 18, which was concordant with d-values of water samples taken in 1999. The IAEA/WMO Global Network for Isotopes in Precipitation (GNIP) showed hydrogen and oxygen isotopic data of monthly rainfall for Jakarta, Jayapura (Irian Jaya) and Darwin (Australia) (IAEA/WMO, 1999). The relation between hydrogen and oxygen isotopic ratio of water samples obtained from springs, streams and rainfall for Flores Island and rainfall for Jakarta, Jayapura and Darwin is shown in Fig. 3. In Fig. 3, the relation between those isotopic compositions of monthly rainfall taken at several points on Bali Island (Shimada et al., 1992a) is also shown. As shown in Fig. 3, small d-values for monthly rainfall were observed for Jayapura, eastern part of the Indonesian archipelago, whereas large d-values for Bali Island, central part of the Indonesian archipelago. The d-values for water samples obtained from Flores Island lie between those at Jayapura 


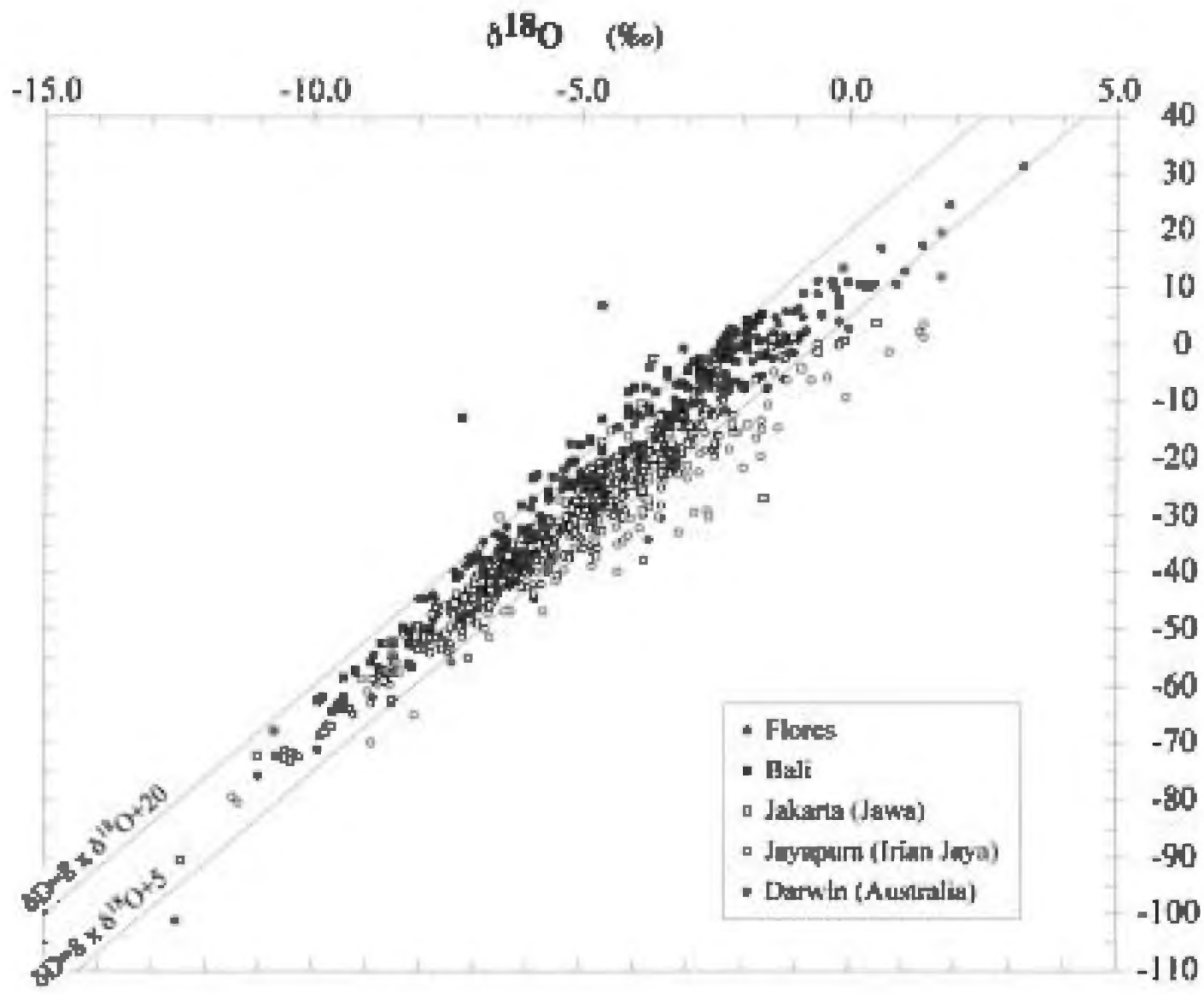

Fig. 3 The relation between hydrogen and oxygen isotopic ratio of rainfall for Flores Island, eastern Indonesia, and rainfall for Bali, Jakarta (Jawa), Jayapura (Irian Jaya) and Darwin (Australia).

and the island of Bali, and were close to those at Jakarta and Darwin.

As shown in Table 1, precipitation amounts at the Inerie V. O. and Ebulobo V. O. in 1998-1999 were both more than in 1997-1998, and the rainy monsoon in 1998-1999 was longer than in 1997-1998. On Flores Island, the wind direction in winter is west, whereas it is southeast in summer (e.g. Center for southeast Asian studies, Kyoto University, 1997, p. 25). Thus, it was suggested that the d-value change of the rainfall is due to the isotopic difference of rainfall in winter and summer. The National Oceanic \& Atmospheric Administration (NOAA) showed that the tropical Pacific area was in the El Nino condition from spring 1997 to summer 1998 and in the La Nina condition from autumn 1998 to spring 1999 and summer 1999 to spring 2000 (NOAA, 2002). Generally in the El Nino condition, the precipitation amount in Indonesia is smaller than in the La Nina and normal conditions. As shown in Table 1, precipitation amounts for the Inerie V. O. and Ebulobo V. O. in 1998-1999 were both larger than in 19971998, which is concordant with the climatic condition of this period. Thus, it may be also suggested that the change of d-value of rainfall was affected by the climatic condition of this area.

\subsection{The gradients of isotopic composition with elevation}

The relation between the elevation of sampling points and hydrogen isotopic composition of water samples, and relation between the elevation and oxygen isotopic composition are shown in Figs. 4 and 5, respectively. Regression lines were as follows:

$$
\begin{aligned}
& \delta \mathrm{D}(\%)=-(0.0098 \mathrm{H} \pm 0.0013)-(29.3 \pm 1.2), \mathrm{r}^{2}=0.653 \\
& \delta{ }^{18} \mathrm{O}(\% 0)=-(0.00128 \mathrm{H} \pm 0.00023)-(5.35 \pm 0.21), \mathrm{r}^{2}=0.499
\end{aligned}
$$
where $\mathrm{H}$ denotes the sampling altitude in meters.

As shown in Table 3, altitude effects of $-0.98 \% 0 /$ $100 \mathrm{~m}$ for hydrogen isotopic composition and of $-0.13 \% / 100 \mathrm{~m}$ for oxygen isotopic composition were within the range of elevation / isotope gradients found for other islands. The high elevation / isotope gradients were observed only in the Martha Brae River basin (Ellins, 1992), Bali Island (Shimada et al., 1992b) and high-elevation area of Hawaii Island (Scholl et al., 1996) areas. Since high-elevation mountains $>3000 \mathrm{~m}$ were in those areas except Martha Brae River basin area, the large elevation / isotope gradient may be due to the existence of a 


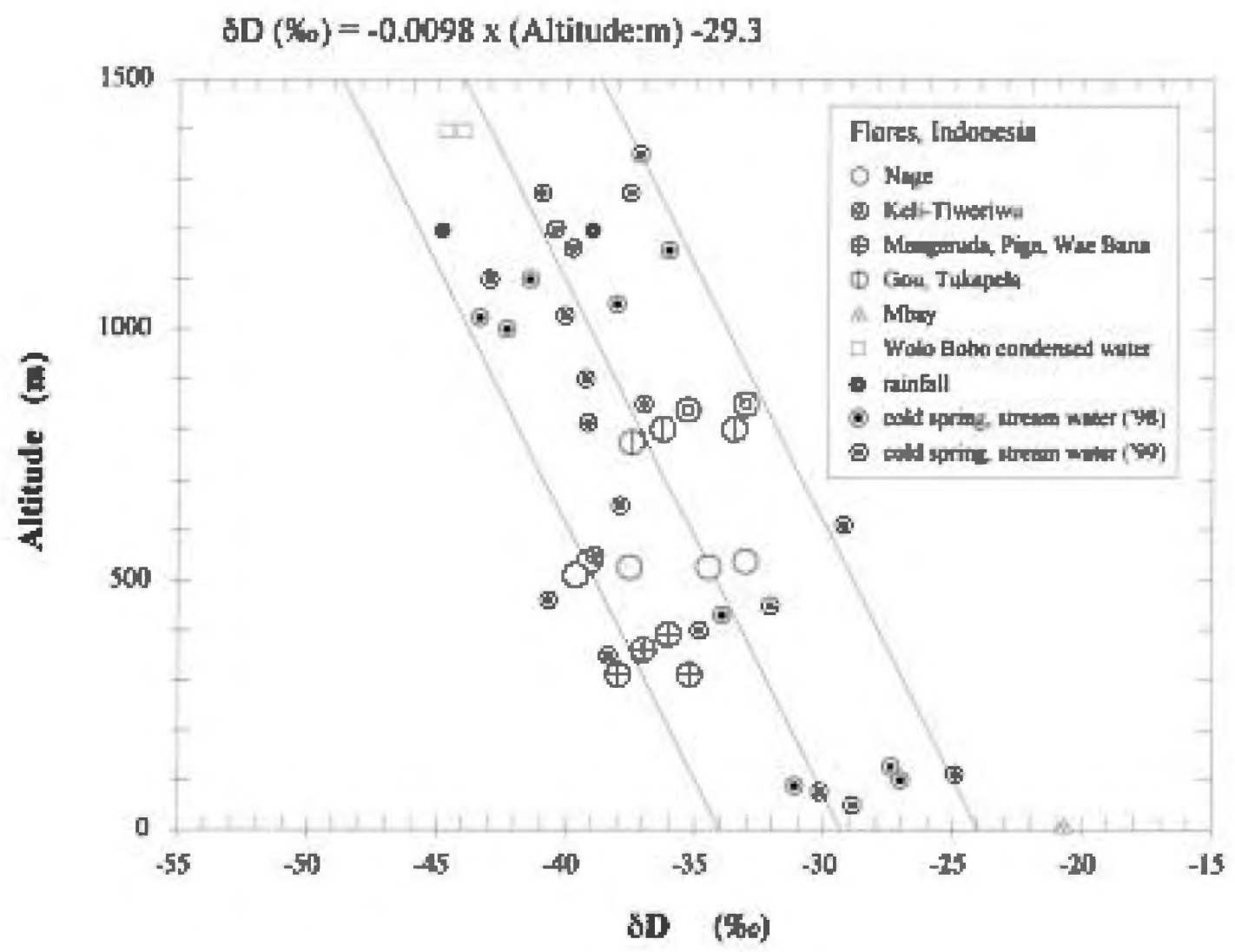

Fig. 4 The relation between sampling altitudes and hydrogen isotopic compositions of water samples.

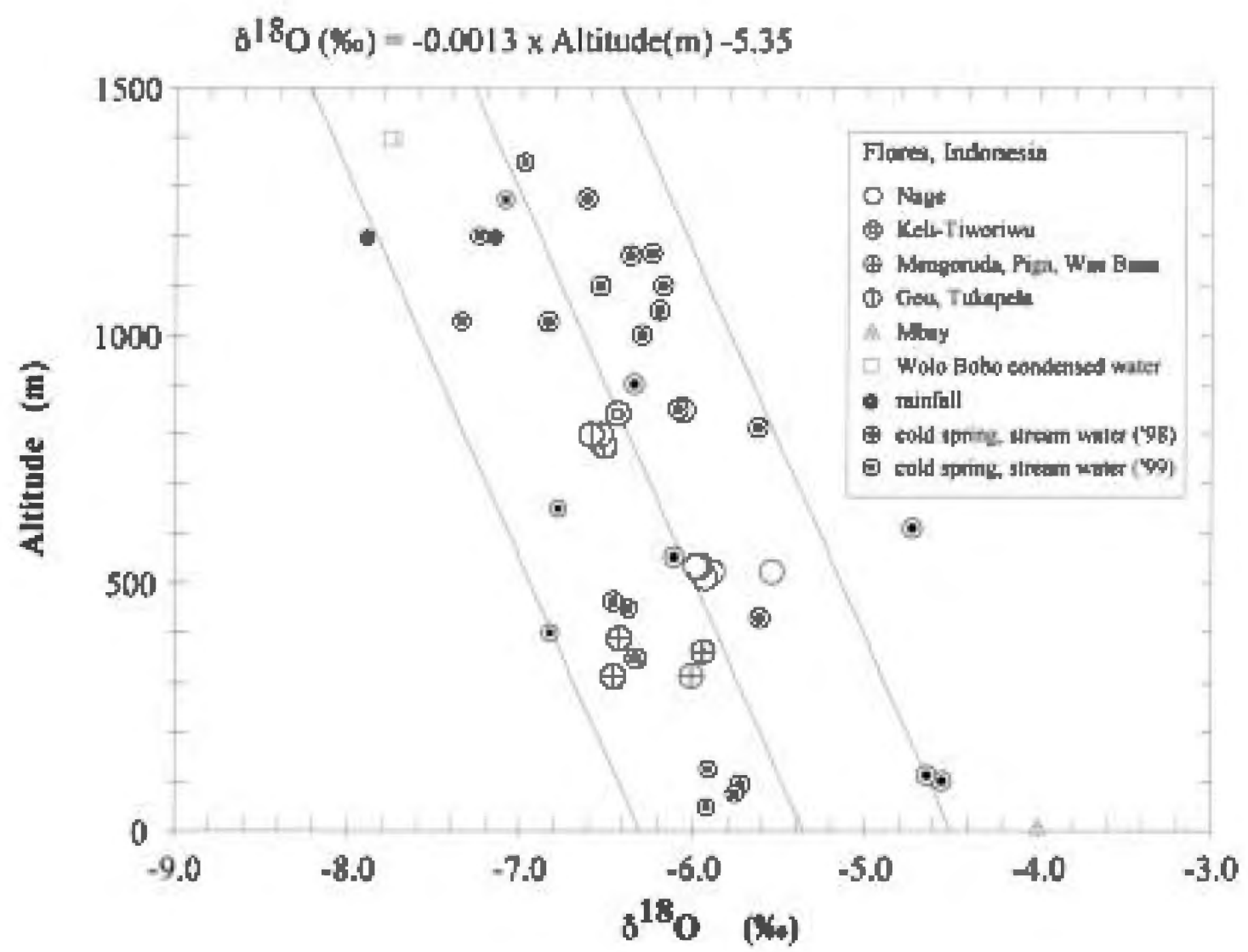

Fig. 5 The relation between sampling altitudes and oxygen isotopic compositions of water samples. 
Table 3 Gradients of isotopic composition with elevation from several islands.

\begin{tabular}{|c|c|c|c|}
\hline I netion & Esspla nis & 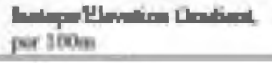 & Dthente \\
\hline 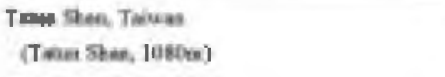 & Heite bones & $+40=-0.158$ & Lis, 1년 \\
\hline 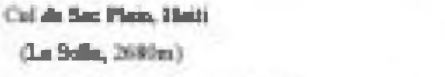 & pritp & 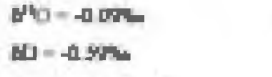 & 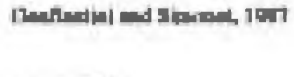 \\
\hline 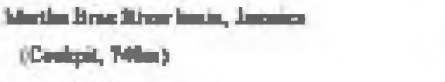 & preiphetion & $\theta=-910+2 \pi$ & Itim, im \\
\hline 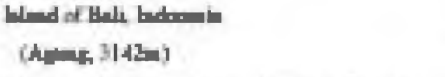 & 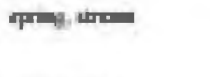 & 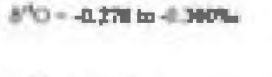 & 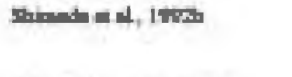 \\
\hline 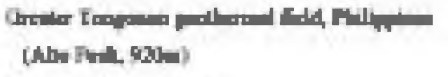 & prptin & 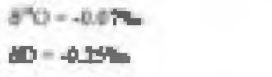 & 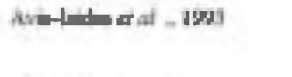 \\
\hline 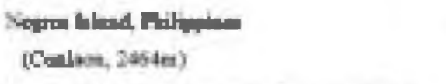 & 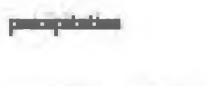 & 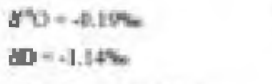 & 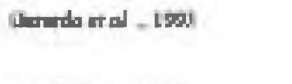 \\
\hline 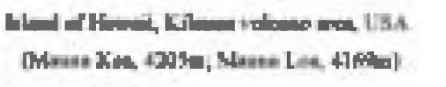 & popiline, prop & 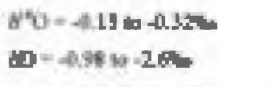 & Idod tral - 19N \\
\hline 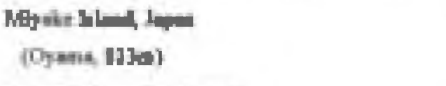 & Propitater & 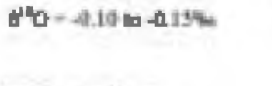 & Thad - tra \\
\hline 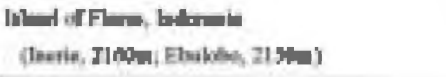 & 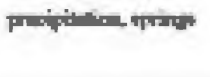 & 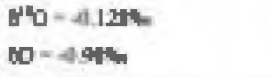 & It 드내 \\
\hline
\end{tabular}

high-elevation area (Scholl et al., 1996).

\section{Conclusion}

Water samples were taken from springs, streams and rainfall within $50 \mathrm{~km}$ of Bajawa City, Flores, eastern Indonesia. Hydrogen and oxygen isotopic compositions of the samples were analyzed.

(1) On the relation diagram between hydrogen and oxygen isotopic compositions, almost all water samples were plotted near the MWL. The sample dvalues taken in 1998 and 1999 were about 10 and 20, respectively. The d-value change may be due to the isotopic difference of rainfall in winter and summer. (2) Altitude (topographical) effects for hydrogen and oxygen isotopic compositions of subsurface water in this area were shown by following regression lines.

$\delta \mathrm{D}(\%)=-0.0098 \mathrm{H}-29.3$

$\delta{ }^{18} \mathrm{O}(\% 0)=-0.00128 \mathrm{H}-5.35$

where $\mathrm{H}$ denotes the sampling altitude in meters. The elevation / isotope gradients observed in the Bajawa area were within the range of those found for other islands.

\section{References}

Avis-Isidro, R. R., Solana, R. R., D'Amore, F., Nuti, S. and Gonfiantini, R. (1993) Hydrology of the Greater Tongonan geothermal system, Philippines, as deduced from geochemical and isotopic data. Geothermics, 22, 435-449.

Center for southeast Asian studies, Kyoto University (1997) Encyclopedia for Southeast Asia -climate, ecology and environment-. Kobundo, Tokyo, 617p (in Japanese).

Craig, H.(1961) Isotope variations in meteoric waters. Science, 133, 1702-1703.

Dansgaard, W. (1964) Stable isotopes in precipitation. Tellus, 16, 436-468.

Ellins, K. K. (1992) Stable Isotopic study of the groundwater of the Martha Brae River basin, Jamaica. Water Resources Research, 28, 1597-1604.

Gerardo J. Y., Nuti, Y. S., D'Amore, F., Seastres, J. S. Jr. and Gonfiantini, R. (1993) Isotopic evidence for magumatic and meteoric water recharge and the processes affecting trservoir fluids in the Palinpinon geothermal system, Philippines. Geothermics, 22, 521-533.

Gonfiantini, R. and Simonot, M. (1987) Isotopic investigation of groundwater in the Cul-deSac Plain, Haiti. in Isotope Techniques in Water Resources Development, IAEA-SM299, Vienna, IAEA, 483-504.

Hamilton, W. (1979) Tectonics of the Indonesia region. U. S. Geol. Surv. Prof. Pap., 1078, $345 \mathrm{p}$.

IAEA/WMO (1999) Global Network for Isotopes in Precipitation. The GNIP Database. Release 3, October 1999, URL:http://www.iaea.org/ programs/ri/gnip/gnipmain.htm,

(IAEA, 1969, 1970, 1971, 1973, 1975, 1979, 1983, 1986 and 1990, Environmental Isotope Data No.1-9: World survey of isotope concentration in precipitation. Technical Report Series, Nos.96, 117, 129, 147, 165, 192, 226, 
264 and 311).

Kazahaya, K. and Yasuhara, M. (1994) A hydrogen isotopic study of spring waters in Mt. Yatsugatake, Japan; Applocation to groundwater recharge and flow processes. Journal of Japanese Association of Hydrological Science, 24, 107-119 (in Japanese with English abstract).

Liu, K. (1984) Hydrogen and oxygen isotopic compositions of meteoric waters from the tatun Shan area, northern Taiwan. Bull. Inst. Earth Aci. Acad. Sinica, 4, 159-175.

Muraoka, H., Nasution, A., Urai, M., Takahashi, M. and Takashima, I. (1999) Regional geothermal geology of the Ngada district, central Flores, Indonesia. 1998 Interim Report of Geological Survey of Japan, Research Cooperation Project on the Exploration of Small-scale Geothermal Resources in the Eastern Part of Indonesia (ESSEI), $17-46$.

NOAA (2002) URL: http://www.ogp.noaa.gov/ enso.

PERTAMINA (The Indonesian State Oil Company) (1994) Indonesia Geothermal Reserves and Resources. 45p.

Scholl, M.A., Ingebrisen, S.E., Janik, C.J. and Kauahikaua, J.P. (1995) An isotope hydrology study of the Kilauea volcano area, Hawaii. U.S. Geological Survey Water Resources Investigation Report, 95-4213, 44p.

Scholl, M.A., Ingebrisen, S.E., Janik, C.J. and Kauahikaua, J.P. (1996) Use of precipitation and groundwater isotopes tointerpret regional hydrology on a tropical volcanic island: Kilauea volcano area, Hawaii. Water
Resources Research, 32, 3525-3537.

Shimada, J., Itadera, K., Nakai, N., Suprapta, D.N. and Gara, W. (1992a) Stable isotope ratio in precipitation as an input of hydrological cycle. Water cycle and water use in Bali island. Researches related to the UNESCO's International Hydrological Programme in Japan 1988-1990, ed. Kayane, I. $105-115$.

Shimada, J., Shimmi, O., Tanaka, T., Nakai, N. and Itadera, K. (1992b) The effect of subak system to the regional evaporation. Water cycle and water use in Bali island. Researches related to the UNESCO's International Hydrological Programme in Japan 1988-1990, ed. Kayane, I. 175-188.

Takahashi, M., Urai, M., Yasukawa, K., Muraoka, H., Matsuda, K., Akasako, H., Koseki, T., Hisatani, K., Kusnadi, D., Sulaeman, B. and Nasution, A. (2002) Geochemical characteristics of hot spring water in Bajawa area, central Flores, Indonesia. Bull Geol. Surv, Japan, 53, 183-199.

Tang, C., Shindo, S. and Machida, I. (1998) Topographical effects on the distributions of rainfall and ${ }^{18} \mathrm{O}$ distributions: $\mathrm{A}$ case in Miyake Island, Japan. Hydrological Processes, 12, 673-682.

Yurtsever, Y. and Gat, J. R. (1981) Atmospheric waters, in Stable Isotope Hydrology, Deuterium and Oxygen-18 in the Water Cycle, IAEA Tech. Rep. Ser. no.210, eds Gat, J. R. and Gonfiantini, IAEA, Vienna, 103-143.

Received September 14, 2001

Accepted February 21, 2002

\title{
インドネシア，フローレス島中部バジャワ地域の地下水の水素・酸素同位体組成 \\ 高橋正明・浦井 稔・安川香澄・村岡洋文・松田鉱二・赤迫秀雄・小関武宏・久谷公一・ \\ Dedi KUSNADI・Bangbang SULASEMAN・Terry SRIWANA・Asnawir NASUTION
}

\begin{abstract}
要旨
インドネシア東部, フローレス島中部のバジャワ周辺 $50 \mathrm{~km}$ 以内にある湧水, 河川水及び降水を採 取し，その水素・酸素同位体組成を分析した。

（1）水素-酸素同位体組成図上では，水試料は天水線近くにプロットされ，そのd 值は 1998 年採取試 料は約 10, 1999 年採取試料は約 20 であった。d 值の变化は, 冬季と夏季の降水の同位体組成の違いを 反映している可能性が考えられる.

(2) 同位体標高効果は，水素同位体組成で $-0.98 \%$ / $100 \mathrm{~m}$, 酸素同位体組成で $-0.13 \% 0 / 100 \mathrm{~m}$ であっ た.これらの值は他の島で観测される值の範囲内である。
\end{abstract}

